\title{
Impact of Government Expenditure on Economic Growth in Nigeria, 1970-2019
}

\author{
Chandana Aluthge ${ }^{1}$, Adamu Jibir ${ }^{2}$, and Musa Abdu ${ }^{2}$
}

This study investigates the impact of Nigerian government expenditure (disaggregated into capital and recurrent) on economic growth using time series data for the period 1970-2019. The paper employs Autoregressive Distributed Lag (ARDL) model. To ensure robustness of results, the study accounts for structural breaks in the unit root test and the co-integration analysis. The key findings of the study are that capital expenditure has positive and significant impact on economic growth both in the short run and long run while recurrent expenditure does not have significant impact on economic growth both in the short run and long run. The study recommends that government should increase the share of the capital expenditure especially on meaningful projects that have direct bearing on the citizen's welfare. Government should also improve the spending patterns of recurrent expenditure through careful reallocation of resources toward productive activities that would enhance human development in the country.

Keywords: ARDL, capital expenditure, endogenous growth model, economic growth, recurrent expenditure

JEL classification: C32, H54, H50, O40, O41

DOI: $10.33429 / \mathrm{Cjas} .12121 .6 / 6$

\section{Introduction}

Government expenditure remains an important instrument utilised in the process of development. It plays a pivotal role in the functioning of any economy at almost all stages of growth and development. Most developing and developed countries today use public expenditure to improve income distribution, direct the allocation of resources in desired areas, and influence the composition of national income (Assi et al., 2019; Vtyurina, 2020; World Bank, 2008). In developing countries for instance, the variation in government spending pattern is not only projected to guarantee stabilization but also to spur economic growth and expand employment opportunities

\footnotetext{
${ }^{1}$ Department of Economics, University of Colombo, Sri Lanka

${ }^{2}$ Department of Economics, Gombe State University, Nigeria
} 
Impact of Government Expenditure on Economic Growth in Nigeria, 1970-2019

Aluthge et al.

(World Bank, 2015).

Empirical evidences on the effect of government expenditure on output growth especially for developing economies like Nigeria, present two opposing views, some suggesting that government expenditure has negative effect on output growth (Abu \& Abdullahi, 2010; Devarajan, Swaroop \& Zou, 1996; Fölster \& Henrekson, 2001; Gukat \& Ogboru, 2017; Nurudeen \& Usman, 2010; Saidu \& Ibrahim, 2019; Segun \& Adelowokan, 2015). In contrast, other studies established that government expenditure promotes output growth and development of a country (Aigbeyisi, 2013; Akanbi, 2014; Ahuja \& Pandit, 2020; Awode \& Akpa, 2018; Nyarko-Asomani, et al., 2019; Bose, Haque \& Osborn, 2007; Idris \& Bakar, 2017; Ihugba \& Njoku, 2017; Jibir \& Aluthge, 2019a; Jibir \& Babayo, 2015; Srinivasan, 2013; Olayungbo \& Olayemi, 2018).

The conflicting results can be attributed to differences in methodological approach, scope, or dataset. Irrespective of which of the argument may be more convincing, what remains obvious is that there is need for further studies to go beyond their specifications and methodologies. Thus, the focus of this study is to empirically investigate the impact of government expenditure on economic growth in Nigeria using latest data and ARDL model with structural break.

The contribution of this paper to the body of knowledge is threefold: first, the study covers a large period - between 1970 and 2019, which is sufficient for time series analysis. Based on this timeline, the research is able to investigate the long-run and short-run impact of government expenditure on economic growth in Nigeria. Second, the impact of the structural breaks which affect the quality of findings is taken into cognizance by this study through the use of more robust techniques of structural break approach to the estimation of time series data. Epochal events like oil gluts of 1980s, Structural Adjustment Programme (SAP) of 1986, 2008/2009 global economic crisis, oil booms of both 1970s and 2010-2014, fourth republic democracy in Nigeria are expected to have caused sudden up and down swings in both GDP and government expenditure, which altogether justify the application of structural break analysis. This is a headway in this line of research as majority of the previous studies on Nigeria, (Idris \& Bakar, 2017; Ihugba \& Njoku, 2017; Saidu \& Ibrahim, 2019; 
Jibir \& Aluthge, 2019a; Jibir, et al., 2018; Nurrudeen \& Usman, 2010; Olayungbo \& Olayemi, 2018; Onifade, et al., 2020; Usman et al., 2011) overlooked it in their methodological approaches which may affect the reliability of their findings. The few available studies (Awode \& Akpa, 2018; Oyinlola \& Akinnibosun, 2013) that incorporated structural break analysis are mostly not up to date and did not address the issue of converting the capital investment, as a flow variable, to capital stock. This measurement problem might have affected the findings of those studies. Although Onifade, et al., (2020) is the latest study on Nigeria; it has a lot of shortcomings including absence of structural break analysis and failure to convert capital investment, as a flow variable, to capital stock.

Another improvement on the existing literature is the use of country-specific data as opposed to a cross-country analysis. Majority of studies (Churchill, Ugur \& Yew, 2016; Devarajan, et al., 1996; Lin, Ali \& Lu 2015; Ahuja \& Pandit, 2020) on the nexus between public spending and output growth applied cross-country approach. Country-specific studies have the merit of portraying the true picture of the nexus between public spending and output growth as opposed to the masking effect of cross-country studies (Devarajan et al., 1996). The study also measures the variables particularly public expenditure where it applied perpetual inventory method to control for depreciation in capital expenditure and transform it to stock variable unlike majority of the previous studies that measured it as a flow variable. This is so because the specification of production function in the growth model signifies that the inputs of the capital variables are in their accumulative or stock forms not flow (Fölster \& Henrekson, 2001). This study deviates from the previous ones as it is underpinned in Barro's (1991) growth theory. By filling methodological and theoretical gaps, the findings provide a different perspective to analysts and academia to explain government expenditure-growth nexus. By addressing the methodological loopholes overlooked by earlier studies, the findings could be more robust and reliable in formulating more effective fiscal policy in Nigeria. As corroborated by Fölster and Henrekson (2001), clear and appropriate link between government spending and economic growth could be ascertained when methodological and measurement problems are properly addressed. 
Impact of Government Expenditure on Economic Growth in Nigeria, 1970-2019

Aluthge et al.

The remaining part of the paper is organized in the following manner: after the introduction in Section 1, Section 2 covers literature review. The methodology and discussions of the results are presented in Sections 3 and 4 respectively. The last section contains the conclusion and policy recommendations.

\subsection{Literature Review}

\subsection{Theoretical Literature}

Classical economists particularly Adam Smith advocated minimum government intervention in providing public goods, law and order and those investments that cannot be adequately provided by private sector due to their high risk or unprofitable nature (Jibir \& Aluthge, 2019b). This doctrine dominated the world economy until the unprecedented Great Depression of 1930s that exposed the failure of the classical system. On the contrary, the Keynesian economists supported the use of public expenditure in promoting growth and development by stimulating aggregate demand especially during economic depression. This provides the obvious reason for government participation in economic activities in the modern time. This is because government is needed to correct short term distortions in an economy (Jibir \& Aluthge, 2019b; Singh \& Sahni, 1984) and to create socially optimal direction for growth and development of a country (Ram, 1986). Government also exists so as to provide basic services such as health, education, communication, transportation, among others, through expenditures which have an impact on the wellbeing of citizens and business environment for the private sector (Aladejare, 2019; Jibir \& Aluthge, 2019b; Ukwueze, 2015).

Within the premises of neoclassical growth models of Solow (1956), Cass (1965) and their subsequent modifications, long-run or steady-state economic growth is determined majorly by discount factors (rates of capital depreciation, population growth and technical progress). Although distortionary taxation and productive government expenditures could affect human or physical investment propensities; these changes only affect the steady-state factor ratios, not economic growth rate, as the rate of economic growth transitorily changes and resettles at the old or new steady state (Bleany, Gemmell \& Kneller, 2001). By implications, the neoclassical growth 
models conclude that government spending only affects economic growth rate in the short run. Conversely, endogenous growth models, albeit not all, but those of Barro (1990; 1991) and King and Rebelo (1990) posit that distortionary taxation and productive expenditures will significantly affect both long-run level output path and growth rate with a change in rate of distortionary taxes while it increases with the increase in government productive spending. Endogenous growth models infers that non-distortionary taxation and unproductive government expenditures do not affect the steady-state growth rate (Sala-i-Martin \& Barro, 1995).

Also, Wagner (1883) proposed a theory of government expenditure in economic literature. The law states that as the per capita income of a country rises, the share of public spending to gross domestic product also rises - which connote direct positive relationship between them. Put differently, industrialization-driven growth in per capita income incentivizes government to increase its expenditures with direct bearing on social welfare (education, health, etc.), which in turn encourages industries to produce more goods and services as aggregate demand goes up. Increased industrial production finally raises aggregate output. Since the emergence of Wagner's law, there has been debate over the role of government spending on the performance of an economy both at theoretical and empirical level.

\subsection{Empirical Literature}

Turning to the empirical ground, there is a plethora of studies that investigated the impact of public spending on output growth. These studies are reviewed thematically along the lines of aggregated and disaggregated studies across developed and developing countries. Aggregated studies conducted their analysis by using total government expenditures as one of the independent variables in their respective models. In that respect, Katrakilidis and Tsaliki (2009) in their study of causal nexus between public spending and output growth, using Greece data between 1958 and 2004, demonstrated a long run equilibrium relationship between public spending and output. Similarly, Srinivasan (2013) examines the causal nexus between government expenditure and output growth in India. The results indicate one way causality running from economic growth to government expenditure in short-run and long-run. Forte and Magazzino (2016) examined the nexus between public spending and out- 
Impact of Government Expenditure on Economic Growth in Nigeria, 1970-2019

Aluthge et al.

put growth using Italian data spanning from1861 to 2008 and the finding established a non-linear relationship between public spending and economic growth for Italy. Churchill, Ugur and Yew (2016) investigated the nexus between public spending and output growth, the result upheld the conventional belief that large government size is detrimental to growth. The studies by Gupta (2018) and Diyoke, Yusuf and Demirbas (2017) revealed a strong positive correlation between government spending and economic growth.

In another study by Dudzevičiūtė, Šimelytė and Liučvaitienė (2018) using data for eight European Union member countries found a strong positive association between public spending and economic growth. Idris and Bakar (2017) and Ihugba and Njoku (2017) found positive impact of government expenditure on output growth. Chimobi (2016) investigated national income and government expenditure nexus in Nigeria and found that there is stable long run relationship between the fiscal variable and economic growth.

The above strand of studies contradicts the proposition of neoclassical growth models that government expenditures cannot increase growth rate at steady-state since the economies have all reached their maximum capacities. However, the findings mostly affirm the submissions of Wagner's law that there is a positive nexus between public expenditures and economic growth.

In contrast, Oktayer and Oktayer (2012) investigated the nexus between public spending and output growth using Turkish data for the period 1950-2010 and found no long run co-integration between the variables of interest. Molefe and Choga (2017) analyzed the impact of government expenditure on economic growth in South Africa over the period 1990-2015 using VECM model. Their results suggested that government expenditures have a negative long-run relationship with economic growth. Ebaid and Bahari (2019) using data for Kuwait found a unidirectional causality running from expenditure to economic growth. Additionally, Olayungbo and Olayemi (2018) using Vector Error Correction Model for 1981-2015 Nigerian data established government expenditure have negative and significant impact on economic growth in both short and long runs. While controlling for structural breaks in ARDL model, Awode and Akpa (2018) supported the findings of Olayungbo and Olayemi (2018); 
though the findings of the former are insignificant. These studies' findings neither contradict nor affirm the submissions of neoclassical growth models and Wagner's law. This is debatable given that the findings are established in developing countries battling with bribery and corruption.

Alternatively, disaggregated studies broke up public spending into its major components based on functional, economic, sectoral and cross classifications. On the basis of economic classifications, Kneller, Bleaney and Gemmell (1999), using a panel of 22 OECD countries, find that while productive expenditures enhances growth, unproductive expenditures do not. This is supported by Greiner (2014), in which a positive nexus between public capital expenditure and economic growth was found. Likewise, while applying Gregory-Hansen Structural break technique on 1970-2009 Nigerian data, Oyinlola and Akinnibosun (2013) found that in both short and long run, while capital expenditure has positive and significant influence on economic growth; recurrent expenditure is negatively insignificant in determining economic growth.

Similarly, Ebong, et al (2016) examined the impact of capital and recurrent expenditure on economic growth in Nigeria over the period 1970-2012 using VECM. The result reveals that capital expenditure on infrastructures positively and significantly influences economic growth in both short and long runs. Onifade, et al (2020) using ARDL model and 1981-2017 Nigerian data, discovered that recurrent expenditure negatively impacts on national output whereas capital expenditure, albeit insignificantly, positively affects GDP. The findings of these studies have validated the propositions of Barro's (1990) endogenous model that productive expenditures have the potentials to boost level output and economic growth rate in both short and long runs.

Contrariwise, the finding that productive expenditures contribute to growth is also refuted by Devarajan, et al. (1996) using data from 43 developing countries over 20 years. They found that while the share of current expenditure had a positive effect, the share of capital expenditure had a negative influence on per capita growth. Ali et al. (2013) using data set for Pakistan, discovered that capital expenditure does not promote output growth for the period covered. 
Impact of Government Expenditure on Economic Growth in Nigeria, 1970-2019

Aluthge et al.

In terms of functional classifications, Lin, Ali and Lu (2015) using a panel of 29 OECD countries found a positive relationship between military spending and education and health expenditure. In same token, using ARDL technique on 2004-2019 Afghanistan data, Barlas (2020) found that current expenditures on education and infrastructure have positive impact on economic growth as opposed to security expenditure, which negatively affects economic growth in Afghanistan. In contrast, Phiri (2019) in his analysis of the effect of military expenditure on economic growth found that the current level of defence expenditure are too high and does not support growth and development. Similarly, d'Agostino, Dunne and Pieroni (2019) using large sample data for 109 middle and low income countries found that defense expenditure has negative impact on economic growth.

Cross classification disaggregated studies include Nurrudeen and Usman (2010) showing that very few variables were robust in explaining cross-country variations in growth rates, and these include public educational spending and capital stock. Equally, Atilgan, Kilic and Ertugrul (2017) showed that positive nexus exists between social expenditure on health and economic growth. Babatunde (2018) indicated that expenditures on transport, communication, health and education positively and significantly affect output in Nigeria. However, Usman et al. (2011) applied multivariate time series framework for Nigeria to analyze the impact of public spending on output growth. The findings revealed that expenditure on administration, communication, education and transport had negative impact on economic growth in the short run. Further, the co-integration result reveals a long run relationship between public spending and output growth. In another disaggregated analysis, Gukat and Ogboru (2017) found that administrative and community services expenditure show negative effect on growth.

It is apparent from the above that there are mixed, conflicting and inconclusive findings on the relationship between public spending and output growth. Some findings established that aggregate public spending has negative effects on economic growth by crowding out private investment and resulting in inefficiency. This might have occurred (though not directly implied by the studies) as a result of 'too big government size', which is a situation whereby government intervenes in economy beyond the 
optimal proportion. Also, there is a set of studies which observed that certain components of public spending have positive and significant impacts on output growth and these components include spending on human capital (health and education). This could be due to increase in labour productivity directly caused by improved human capital. The last set of studies found out that aggregate public expenditure significantly and positively determined economic growth.

The findings of existing studies on the impact of government expenditure on economic growth in Nigeria are constrained by time scope, econometric issues and measurement problems. Although this is well researched area; Fölster and Henrekson, (2001) pinpoint that most of the earlier studies in the area have serious econometric and measurement predicaments, which if properly addressed would be a great contribution to knowledge. This is self-convincing as better understanding and reliable connection between government expenditure and economic growth could be established. Given that majority of Nigerian studies (including Onifade, et al, 2020) did not address the issue of structural break, converting capital expenditure into stock variable and they are mostly not up to date, this study seeks to address these research gaps so as to establish more robust and reliable findings and in turn contribute to the body of knowledge on the on-going debate of the impact of government expenditure on economic growth.

\subsection{Stylized Facts}

Over the years, Nigerian governments have been increasingly voting and spending huge amount of money on operating expenses, overhead cost, and infrastructure, with an expectation that the spending would speed up the process of economic growth and development. However, the prevailing realities in the country seem to suggest that the economy is not experiencing the commensurate rate of output growth. Available statistics suggest that Nigeria's public expenditure as proportion of GDP has rather dipped down between 1970 and 2019. For instance, the average public expenditure as a proportion of GDP for the period 1970-79 stood at about 21.07 percent, which slightly rose to 21.57 percent in 1980-89. However, it went down continually; 14.07 and 7.67 percents in 1990-99 and 2000-09 respectively. This means Nigerian government reduces its size and involvement in the economic activities. 
Impact of Government Expenditure on Economic Growth in Nigeria, 1970-2019

Aluthge et al.

Table 1: Trend Analysis of Government Expenditures-Economic Growth Nexus

\begin{tabular}{|c|c|c|c|c|c|c|}
\hline Year & $\begin{array}{l}\text { Govt. Exp. } \\
\text { (N'million) }\end{array}$ & $\%$ of GDP & $\begin{array}{l}\text { Govt. Exp. } \\
\text { Growth Rate } \\
(\%)\end{array}$ & $\begin{array}{l}\text { Rec. Exp. } \\
\% \text { of Govt. } \\
\text { Exp. }\end{array}$ & $\begin{array}{l}\text { Cap. Exp. } \\
\% \text { of Govt. } \\
\text { Exp. }\end{array}$ & $\begin{array}{l}\text { GDP } \\
\text { Growth } \\
\text { Rate }(\%)\end{array}$ \\
\hline $1970-79$ & 4566.60 & 21.07 & 31.70 & 56.52 & 43.48 & 7.00 \\
\hline $1980-89$ & 17,793 & 21.57 & 23.20 & 53.86 & 46.14 & -0.93 \\
\hline 1990-99 & 302,098 & 19.54 & 41.24 & 51.13 & 48.87 & 2.31 \\
\hline 2000-09 & $1,833,034$ & 14.09 & 15.82 & 69.12 & 30.88 & 7.68 \\
\hline 2010-19 & $6,945,644.32$ & 7.68 & 5.22 & 62.49 & 16.16 & 3.65 \\
\hline
\end{tabular}

Source: Authors' Computation using CBN Statistical Bulletin and World Development Indicator, 2020.

This could be linked to the process of deregulating the economy that begun in 1980s with introduction of Structural Adjustment Programme. More so, between 1970 and 1999, capital expenditure as a proportion of total government expenditures had been high and on increase until 2000-09 when it dipped to 30.88 percent from an average of about 48.87 percent and further decline to 16.16 percent in 2010-19. This falling trend may be connected to the global economic crisis of 2008/09 and process of transition from military regime to democratic dispensation between 1998 and 1999. Additionally, total government expenditure has been on the increase unabatedly for the period 1970-2019 in Nigeria and a decadal breakdown shows that average annual growth rate of total government expenditure are around 31.70, 23.20, 41.24, 15.82 and 11.82 percents over the periods 1970-79, 1980-89, 1990-99, 2000-09 and 20102019 respectively (CBN, 2020).

Recurrent expenditure constitutes mostly the chunk of the expenditures with exception of 1979, 1980 and 1999. Conversely, Nigeria's GDP has instead grown at a slower rate than the rate at which government expenditure grew. For example, Nigeria's GDP has grown on average rate of about 7 percent for the period 1970-79 but it dropped by an average rate of 0.94 percent over the period 1980-89 due to several recessions in most of the years. More so, the GDP witnessed moderate annual growth rates of 2.31, 7.68 and 4.05 percent over the decades 1990-99, 2000-09 and 2010-19 respectively (World Bank, 2020). Figure 1 clearly depicts that government expenditure and GDP are positively associated with each other as they move on the same trend over the period 1970-2019. This confirms the proposition of Wagner's 
law that government spending and national income are directly related.

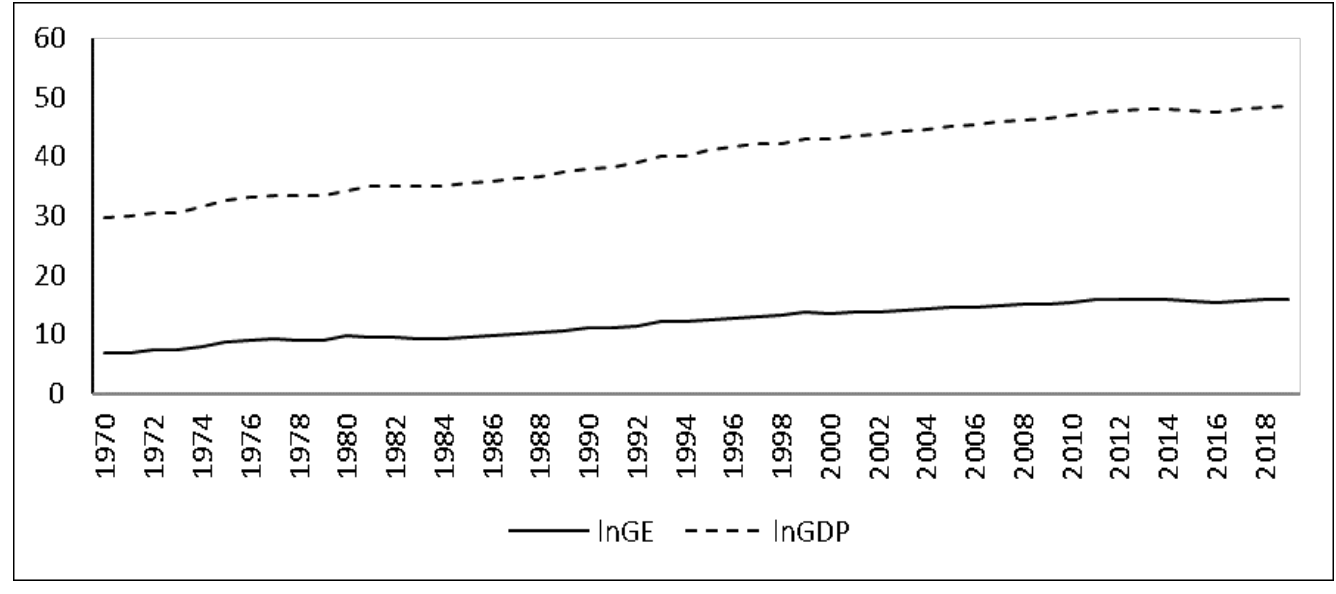

Figure 1: Trend Analysis of Government Expenditure and GDP

The trend analysis for government expenditure-growth nexus of the economy would give rise to information that is particularly useful for Nigeria, where the allocation of limited public resources between sectors is an issue of paramount importance for policy makers.

\subsection{Data and Methodology}

\subsection{Data}

The study uses time series secondary data for the analysis of the impact of government expenditure on economic growth for the period 1970-2019. Data on relevant variables, including non-oil revenue, government expenditure (capital and recurrent), Gross Domestic Product and trade openness are sourced from Statistical Bulletin of the Central Bank of Nigeria while data for labour force and inflation are obtained from the World Development Indicators of the World Bank.

\subsection{Model Specification}

Within the neoclassical context, public expenditure only affects a country's transitional growth rate; but the steady-state growth rate stays unchanged (Arrow \& Kurz, 1970). However, the recent proliferation of studies on endogenous growth has produced a number of models connecting public capital with a country's long-term 
Impact of Government Expenditure on Economic Growth in Nigeria, 1970-2019

Aluthge et al.

growth rate (Barro, 1990; Devarajan, et al., 1996; Gemmell, et al. 2016; King \& Rebelo, 1990). Endogenous growth theories, like Barro (1990; 1991), suggest that public spending would have both temporary and lasting effects on economic growth of a country (Devarajan et al., 1996). The innovative characteristic of the public-policy endogenous growth models of Barro (1990) and Sala-i-Martin and Barro (1995) is that public expenditure can determine both the level of the output path and the steadystate growth rate of a country (Devarajan et al., 1996; Gemmell et al., 2016). This provides the avenue for the application of the public-policy endogenous growth models in the analysis of the impact of public expenditure on economic growth.

Thus, since the goal of this study is to investigate the impact of government expenditure on economic growth in Nigeria, we apply the public-policy endogenous growth model with public capital as one of the factors. Public expenditure is therefore, used as proxy for capital which is further decomposed into capital and recurrent expenditures. We use an aggregate production function (Yt) which integrates public capital expenditure. The Cobb-Douglas production function as the aggregate production function of the economy is specified within the framework of endogenous model in equation 1 :

$$
Y_{t}=f\left(K_{t}, g_{1 t}, g_{2 t}\right)
$$

where $\mathrm{Y}$ is the level of output, $\mathrm{K}$ is the available private capital, $\mathrm{g}_{1}$ and $\mathrm{g}_{2}$ are government expenditure components and $t$ is the time period. Following Barro (1990), Devarajan et al., (1996) and Gemmell et al. (2016), we leave out private capital as a separate argument in the production function. Like other studies, we consider controlling for other relevant variables in the model. We have incorporated labour force, inflation, trade openness and non-oil revenue into the model. The selection of the control variables is based on their relevance within the context of Nigerian economy. In particular, controlling for labour force in the model is essential as labour is one of the most important factors in production function of most growth models ranging neoclassical to endogenous growth models. For instance, neoclassical growth models suggest that steady-state conditions are determined by discount factors, to which population growth rate (measured by changes in labour input over time) is part and parcel. Given the level of how most economies are integrated through series of bilat- 
eral and multilateral strategies, including trade openness, as a measure of integration, in growth model is essential in making the model more robust and realistic. Again, to help the model to capture the macroeconomic (in)stability, inflation is fundamental as it measures the changes in level of all important prices, particularly consumer goods. In view of the Nigerian government's efforts to diversify the economy due to dwindling oil revenue, including non-oil revenue in the model is critical as it could fairly measure the diversification's efforts.

We therefore rewrite equation 1 by considering public capital and accommodating other control variables as:

$$
Y_{t}=f\left(K_{t}, g_{1 t,} g_{2 t}, Z_{t}\right)
$$

where: $Y, g_{1}$ and $g_{2}$ remain as previously defined while $\mathrm{Z}$ stands for control variables. Thus, equation 2 can be re-specified as:

$$
G D P=(C A P, L F, R E C, T P N, I N F, N O I L R)
$$

where: GDP $=$ Gross domestic product, $\mathrm{CAP}=$ capital expenditure, $\mathrm{LF}=$ Labour force, $\mathrm{REC}=$ recurrent expenditure, $\mathrm{TPN}=$ Trade openness, $\mathrm{INF}=$ Inflation, NOILR $=$ Non-oil revenue.

Similarly, equation 3 can be re-specified in econometric form as:

$$
\begin{aligned}
\operatorname{Ln}(G D P)= & \alpha_{0}+\alpha_{1} \operatorname{Ln}(C A P)+\alpha_{2}(L F)+\alpha_{3} \operatorname{Ln}(R E C)+\alpha_{4}(T P N)+\alpha_{5}(I N F)+ \\
& \alpha_{6} \operatorname{Ln}(N O I L R)+\varepsilon_{t}
\end{aligned}
$$

All variables remain as previously defined in equation 3 .

\subsection{Definition and Measurement of Variables}

There is intense debate in the literature regarding the importance of transforming public capital to a stock variable in a growth model (Berlemann \& Wesselhöf, 2014; Kamps, 2006). This is because the depreciation of capital is assumed to be proportional to the capital stock. Thus, over the past decades, there are many different approaches developed by different scholars such as Goldsmith, (1951), Harberger (1978), Griliches (1980), Kamps (2006), Berlemann and Wesselhöf (2014), among others, to be used in transforming public capital to capital stock in order to account for depreciation pattern of capital goods before estimation. For the purpose 
Impact of Government Expenditure on Economic Growth in Nigeria,

of this study, we adopted Perpetual Inventory Method (PIM) propounded by Goldsmith (1951) and later refined by Berlemann and Wesselhöf (2014). The selection of the PIM is informed by the fact that it is the most often used method and has the ability to interpret an economy's public capital as an inventory (Berlemann \& Wesselhöf, 2014). Therefore, the data for capital expenditure is obtained by adding total capital investment and transformed to stock variable using perpetual inventory method to take into cognizance adjustments to consumption of fixed capital (depreciation of fixed assets) from the investment figures. The perpetual inventory method is expressed in equation 5 :

$$
k_{t}=I_{t}+\left(\frac{k_{t-1}}{1+r}\right)
$$

where: $K_{t}=$ Capital stock at current period, $I_{t}=$ Investment at current period, $K_{t-1}=$ Capital stock at previous period, $\mathrm{r}=$ Rate of depreciation at 5 percent.

National Bureau of Statistics (2019) refers labour force population as all persons aged 15 to 64 years who are willing and able to work regardless of whether they have a job or not. Recurrent expenditure refers to government expenditure on day to day activities such as salaries and wages, overhead cost, among others. The variable of non-oil revenue is measured by adding the federally collected revenue from nonoil sources - which comprises of taxes and other income generated from services rendered by government. Furthermore, trade openness, inflation and GDP remain as previously defined and measured. While inflation, trade openness and labour force are treated in percentages, all the remaining variables are applied using their log forms to ensure unification of units of measurement.

\subsection{Estimation Procedure}

\subsubsection{Unit Root Test}

This study applies Augmented Dickey-Fuller test developed by Dickey and Fuller (1978) and Philips-Perron test propounded by Philips and Perron (1988) to ascertain the stationarity status of the variables used in the study. However, considering the study period chosen, there is tendency to have presence of breaks in the data. 
The study therefore applied the Bai and Perron test developed by Bai and Perron (2003) for the structural break estimation. Perron (1989:7) demonstrated that "the standard unit root tests can lead to false acceptance of a unit root null hypothesis when the series is confronted with structural break(s)". Moreover, the sample period of our study (1970-2019) covers a number of shocks especially the Structural Adjustment Program of 1986 and transition from military to democracy in 1999. More so, Nigeria is an oil exporting country and therefore fluctuations in the prices of oil or gas in the foreign market may likely create breaks in the data series. We expect these major breaks would have significant impact on macroeconomic environment in Nigeria. Hence, application of unit root test with structural breaks is essential to point the possibility of having structural breaks among the series. More so, the rationale for the use of multiple break techniques is because considering just one endogenous break can be deficient and can result in loss of information in the presence of more than one break in the series (Aladejare, 2019; Lumsdaine \& Papell, 1997).

The Bai and Perron technique developed by Bai and Perron (2003) modified the basic Chow test and developed a model with $m$ breaks ( $m+1$ regimes) to detect unknown multiple structural breaks. The model is presented in equation 6 .

$$
Y_{t}=x_{t}^{l} \alpha+\varsigma_{t}^{l} \delta_{j}+\varepsilon_{t}
$$

where $j=1, Y_{t}$ represents the dependent variable observed at time $t . x_{t}$ and $\varsigma_{t}$, are $(p \times 1)$ and $(q \times 1)$ vectors of the explanatory variables; $\alpha$ and $\delta_{j}$ are vectors of coefficients associated with $x_{t}$ and $\varsigma_{t}$, respectively. $\varepsilon_{t}$ is the usual error term assumed to be independently and identically distributed with zero mean and constant variance.

\subsubsection{ARDL Bounds' Co-integration Technique}

This study relies on the ARDL bounds test approach to co-integration developed by Pesaran et al., (2001) to test for cointegration The ARDL bounds test approach to co-integration has been demonstrated to perform better than other traditional cointegration methods. This is because of its numerous advantages over other long run estimation techniques. It can be applied on variables that are either $\mathrm{I}(1)$ or $\mathrm{I}(0)$ or combination of the two and the approach yields unbiased estimates and its t-statistics are effective even if some of the regressors are endogenous (Harris \& Sollis 2003). 
Impact of Government Expenditure on Economic Growth in Nigeria,

Thus, we specified conditional general form of the ARDL model in equation 7

$$
\begin{aligned}
& \Delta \ln G D P_{t}=\alpha_{0}+\alpha_{1} \ln G D P_{t-1}+\alpha_{2} \ln C A P_{t-1}+\alpha_{3} L F_{t-1}+\alpha_{4} \ln R E C_{t-1}+\alpha_{5} T P N_{t-1} \\
& +\alpha_{6} I N F_{t-1}+\alpha_{7} N O I L R_{t-1}+\sum_{i=1}^{v} \theta_{1 i} \Delta \ln G D P_{t-1}+\sum_{i=0}^{v} \theta_{2 i} \Delta \ln C A P_{t-i}+\sum_{i=0}^{v} \theta_{3 i} \Delta L F_{t-i} \\
& +\sum_{i=0}^{v} \theta_{4 i} \Delta \ln R E C_{t-i}+\sum_{i=0}^{v} \theta_{5 i} \Delta T P N_{t-i}+\sum_{i=0}^{v} \theta_{6 i} \Delta I N F_{t-i}+\sum_{i=0}^{v} \theta_{7 i} \Delta N O I L R_{t-i}+\mu_{t}
\end{aligned}
$$

where: GDP, CAP, LF, TOP, REC, INF and NOILR remain as previously defined. Similarly, $\alpha$ denotes the drift, $v$ denotes the lag lengths, $\alpha_{1}-\alpha_{7}$ are coefficients to be estimated while ln denotes natural logarithms and $\mu_{t}$ is the stochastic error term.

Before bound test was applied to test for long run equilibrium relationship between the variables, ordinary least square (OLS) technique is first utilized using equation 7. The null hypothesis of no co-integration between the variables is tested against alternative hypothesis of the existence of long run relationship between the variables. Thus, the hypothesis can be specified as:

$$
\begin{aligned}
& H_{0}: \alpha_{1}=\alpha_{2}=\alpha_{3}=\alpha_{4}=\alpha_{5}=\alpha_{6}=\alpha_{7}=0 \\
& H_{1}: \alpha_{1} \neq \alpha_{2} \neq \alpha_{3} \neq \alpha_{4} \neq \alpha_{5} \neq \alpha_{6} \neq \alpha_{7} \neq 0
\end{aligned}
$$

where $\alpha_{1}, \alpha_{2}, \alpha_{3}, \alpha_{4}, \alpha_{5}, \alpha_{6}$ and $\alpha_{7}$ remain as previously defined. Lastly, the ARDL methodology applied AIC for the selection of optimal length for the lag level, and choice of best model.

Since the aim of the study is to understand both short and long run dynamics of the impact of public spending on output growth in Nigeria, specification of the long run and short run ARDL approach is important. Hence, the long run of the growth model is expressed in equation 8 : 


$$
\begin{gathered}
\ln G D P_{t}=\alpha_{0}+\sum_{i=1}^{v} \alpha_{1} \ln G D P_{t-i}+\sum_{i=0}^{v_{1}} \alpha_{2} L F_{t-i}+\sum_{i=0}^{v_{2}} \alpha_{3} \ln C A P_{t-i}+\sum_{i=0}^{v_{3}} \alpha_{4} \ln R E C_{t-i} \\
+\sum_{i=0}^{v} \alpha_{5} \ln N O I L R_{t-i}+\sum_{i=0}^{v_{1}} \alpha_{6} I N F_{t-i}+\sum_{i=0}^{v_{2}} \alpha_{7} T P N_{t-i}+\mu_{t}
\end{gathered}
$$

Similarly, to estimate the short run parameters of the growth model when the long run equilibrium exist, the unrestricted ARDL of error correction model is estimated as captured in equation 9:

$$
\begin{gathered}
\Delta \ln G D P_{t}=\alpha_{0}+\sum_{i=1}^{v} \alpha_{1} \Delta \ln G D P_{t-i}+\sum_{i=0}^{v} \alpha_{2} \Delta \ln C A P_{t-i}+\sum_{i=0}^{v} \alpha_{3} \Delta L F_{t-i}+\sum_{i=0}^{v} \alpha_{4} \Delta \ln R E C_{t-i} \\
+\sum_{i=0}^{v} \alpha_{5} \Delta \ln N O I L R_{t-i}+\sum_{i=0}^{v} \alpha_{6} \Delta I N F_{t-i}+\sum_{i=0}^{v} \alpha_{7} \Delta T P N_{t-i}+\theta E C M_{t-i}+\mu_{t}
\end{gathered}
$$

where $\alpha_{1}, \alpha_{2}, \alpha_{3}, \alpha_{4}$ and $\alpha_{5}$ are short-run coefficients of the ARDL model, $\alpha_{0}$ is the constant, $\theta$ is the speed of adjustment in the system and ECM denotes the stochastic error term.

\subsection{Result and Discussions}

\subsection{Unit Root Test}

It is essential to perform the unit root test to ensure that no variable is integrated of an order higher than one. This is because ARDL bounds test is built on I(0) and I(1), therefore estimation of variables beyond I(1) will produce a spurious result. The study utilizes the Bai and Perron unit root test for multiple breaks in addition to Augmented Dickey Fuller and Philips-Perron tests in order to account for possible break(s) in the time series data. Thereafter, structural break-controlled ARDL model is applied using a dummy variable as a regressor.

The tests regression included both an intercept and trend and intercept for both levels and first difference of the variables in order to ensure robustness of results. Table 2 depicts the results of the ADF unit root test at levels and first difference. 
Impact of Government Expenditure on Economic Growth in Nigeria,

Table 2a: Augmented Dickey Fuller (ADF) Unit Root Test Results

\begin{tabular}{|c|c|c|c|c|c|}
\hline \multirow[t]{2}{*}{ Variable } & \multicolumn{2}{|c|}{ At Level } & \multicolumn{2}{|c|}{ First Difference } & \multirow{2}{*}{$\begin{array}{l}\text { Order of } \\
\text { Integration }\end{array}$} \\
\hline & Intercept & $\begin{array}{l}\text { Trend and } \\
\text { Intercept }\end{array}$ & Intercept & $\begin{array}{l}\text { Trend and } \\
\text { Intercept }\end{array}$ & \\
\hline $\operatorname{lnGDP}$ & -0.354 & -2.003 & $-7.871 * * *$ & $-6.654 * * *$ & $\mathrm{I}(1)$ \\
\hline $\operatorname{lnCAP}$ & -1.096 & -2.937 & $-5.570 * * *$ & $-6.876 * * *$ & $\mathrm{I}(1)$ \\
\hline $\ln L$ & -0.420 & -2.077 & $-7.144 * * *$ & $-7.060 * * *$ & $\mathrm{I}(1)$ \\
\hline $\operatorname{lnREC}$ & -0.516 & -2.087 & $-7.762 * * *$ & $-7.841 * * *$ & $\mathrm{I}(1)$ \\
\hline lnNOILR & -0.963 & -1.864 & $-7.199 * * *$ & $-7.238 * * *$ & $\mathrm{I}(1)$ \\
\hline INF & $-3.009 * *$ & $-3.985 * *$ & - & - & $\mathrm{I}(0)$ \\
\hline TPN & -0.765 & -0.998 & $-3.654 * *$ & $-5.765 * *$ & $\mathrm{I}(1)$ \\
\hline
\end{tabular}

Table 2b: Philips-Perron (PP) Unit Root Test Results

\begin{tabular}{|c|c|c|c|c|c|}
\hline \multirow[t]{2}{*}{ Variable } & \multicolumn{2}{|c|}{ At Level } & \multicolumn{2}{|c|}{ First Difference } & \multirow{2}{*}{$\begin{array}{l}\text { Order of } \\
\text { Integration }\end{array}$} \\
\hline & Intercept & $\begin{array}{l}\text { Trend and } \\
\text { Intercept }\end{array}$ & Intercept & $\begin{array}{l}\text { Trend and } \\
\text { Intercept }\end{array}$ & \\
\hline $\operatorname{lnGDP}$ & -0.204 & -2.556 & $-7.098 * * *$ & $-7.098 * * *$ & $\mathrm{I}(1)$ \\
\hline $\operatorname{lnCAP}$ & -1.996 & -2.867 & $-5.126 * * *$ & $-4.910 * * *$ & $\mathrm{I}(1)$ \\
\hline $\operatorname{lnL}$ & -2.283 & -2.219 & $-6.532 * * *$ & $-6.123 * * *$ & $\mathrm{I}(1)$ \\
\hline $\operatorname{lnREC}$ & -0.280 & -2.593 & $-8.515 * * *$ & $-8.510 * * *$ & $\mathrm{I}(1)$ \\
\hline $\operatorname{lnNOILR}$ & -1.011 & -1.735 & $-8.189 * * *$ & $-8.234 * * *$ & $\mathrm{I}(1)$ \\
\hline INF & $-3.908 * *$ & $-3.032 * *$ & - & - & $\mathrm{I}(0)$ \\
\hline TPN & -3.987 & -3.987 & $-8.171 * * *$ & $-8.987 * * *$ & $\mathrm{I}(1)$ \\
\hline
\end{tabular}

Table 2 reports the results of both $\mathrm{ADF}$ and PP tests, which are consistent in establishing same order of integration for each variable. For instance, it can be observed from table 2 that while inflation is stationary at level, other variables (such as capital expenditure, labour force, recurrent expenditure, trade openness and non-oil revenue) are found to be non-stationary at levels but they all became stationary after taking their first difference at 1 percent levels of significance. This depicts that they are all integrated at $\mathrm{I}(1)$. None of the variables is integrated of order 2 (ie I(2)) or beyond making it possible to employ ARDL approach to co-integration for the regression analysis. From the results of ADF and PP tests, it is clear that the ARDL 
approach to co-integration is more appropriate to analyze the data than the Johansen co-integration approach since the results depict the combination of $\mathrm{I}(0)$ and $\mathrm{I}(1)$.

\subsection{Multiple Structural Break Unit Root Test}

In addition to the traditional unit root tests of ADF and PP, this study applied Bai and Perron (2003) unit root test to detect the presence of multiple structural breaks in the dataset used. It can be seen in table 3, Bai-Perron sequentially determined breaks $\left(\operatorname{Sup} F_{T}\right)$ indicates that there are five (5) breaks that could have significant impacts on economic growth in the long run whereas global determined breaks represented by double maximum statistics (UDmax and WDmax) reports 3 and 5 breaks. The final choice is made based on the LWZ criteria (Liu, Wu \& Zidek, 1997), which are robust to serial correlation problems and the test performs relatively well.

Table 3: Multiple Structural Breaks Analysis of the Growth Model

\begin{tabular}{lcl}
\hline & Test Statistics (Scale-Sta) & Critical Values \\
\hline $\operatorname{Sup} F_{T}(0 / 1)$ & 210.4739 & 13.98 \\
$\operatorname{Sup} F_{T}(1 / 2)$ & 169.5414 & 15.72 \\
$\operatorname{Sup} F_{T}(2 / 3)$ & 14.19715 & 16.83 \\
$\mathrm{UDmax}(5)$ & 3267.778 & 14.23 \\
WDmax(5) & 6123.798 & 15.59 \\
Number of selected breaks and the years & \\
Schwarz Criterion & $-2.845405(4)$ & \\
LWZ Criterion & $-1.932490(3)^{* *}$ & $1982(1982-1986) 1993(1993-$ \\
& & $1997)$ 2001(2001-2007) \\
\hline
\end{tabular}

Notes: **Bai-Perron (2003) critical values and statistical significance

at the $5 \%$ level.

Source: Authors' Computation using E-view 10.

LWZ criteria shows the most significant breaks are 3 occurring at 1982, 1993 and 2001. The first breakpoint that occurred at 1982 and extended up to 1986 could be linked to the upward expansion in the price of oil caused by the Arab-Israeli war in the periods 1973-75. This has significantly affected many oil exporting countries like Nigeria (Olowu Laleye \& Ayeni, 2007).

The second breakpoint that started in 1993 and ended in 1997, might be connected to the resultant effect of Structural Adjustment Progamme of 1986 especially the massive privatization and deregulation focus of the programme. In the late 1990s the 
Impact of Government Expenditure on Economic Growth in Nigeria,

government began to privatize many state-run enterprises. The last breakpoint covered the period 2001-2007 and this coincided with the important point when Nigeria returned to democratic dispensation and oil prospects that made more revenue available to the government. It was a period when the economy started to witness huge investments in the private sector, especially service sector (Olowu Laleye \& Ayeni, 2007).

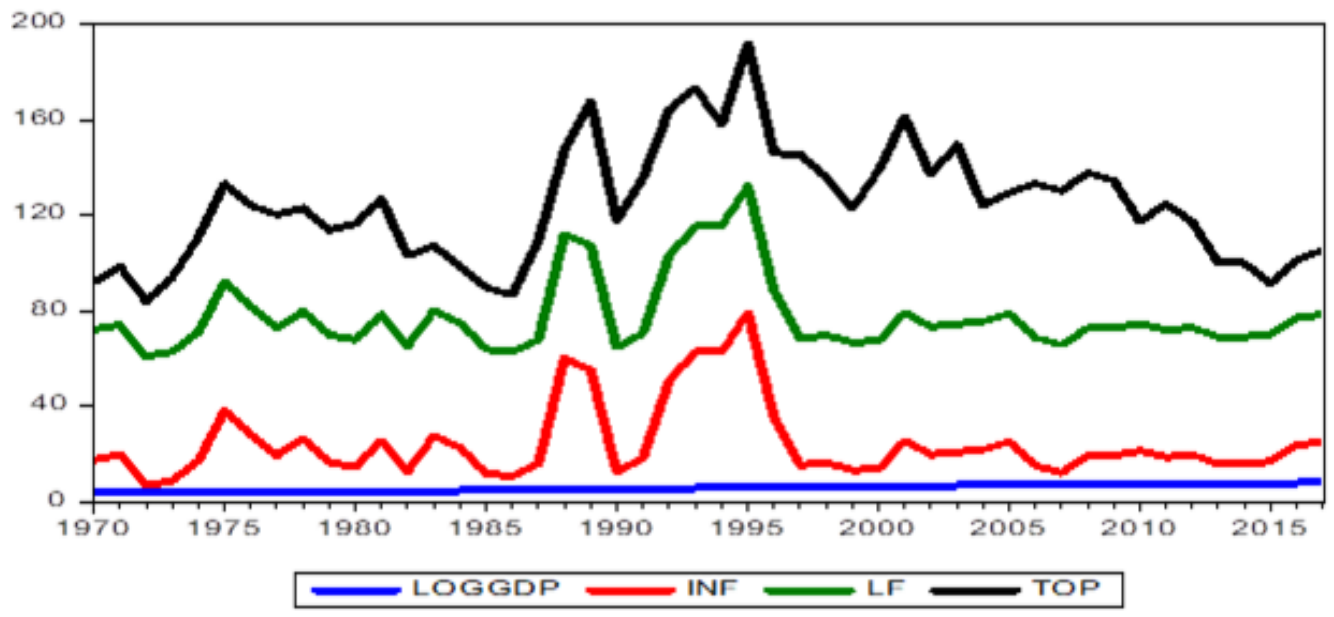

Figure 2: Stacked-Single Graph of LogGDP and the Variables with Noticeable Breaks

Figure 2 shows that there are about four major noticeable breaks in the model and the first break occurred over the period 1972-1977. The second breakpoint covered the period 1986-1990 and the third break happened around the period 1991-1997. The final breakpoint was the one between the periods 2000 and 2007. Given the presence of multiple breakpoints in the growth model, it would be more robust and the findings could be more reliable if the model controls for the breakpoints. To respond to this need, growth ARDL model with breaks is estimated where the break dates are controlled.

\subsection{ARDL Bounds Test}

Having established the presence of three major structural breakpoints in the model, it is pertinent to estimated ARDL model which controlled for the multiple structural breaks by creating dummy for the breakpoints. Table 5 reports the estimated 
ARDL model with structural breaks on impact of government expenditure on economic growth in Nigeria.

Table 4: Multiple Breaks-controlled Bounds Test

\begin{tabular}{lll}
\hline Critical value & $\mathrm{I}(0)$ & $\mathrm{I}(1)$ \\
\hline $10 \%$ & 2.188 & 3.254 \\
$5 \%$ & 2.591 & 3.766 \\
$1 \%$ & 3.54 & 4.931 \\
\hline$F R(R / G)=5.128599$, & $\mathrm{K}=6$ &
\end{tabular}

Table 4 depicts the result of the computed F. statistic when GDP is normalized as the dependent variable in the ARDL-OLS regression. From Table 4, it can be seen that the value of the computed F statistic (5.128599) is greater than the upper critical values at 10 percent, 5 percent and 1 percent levels of significance. The bounds test result shows that the independent variables included in the model are bound together when GDP is the dependent variable. This connotes that there is presence of long run equilibrium nexus between the variables. This permits the estimation of individual long run and short run coefficients of the variables to measure their effect on economic growth.

\subsection{Long Run Relationship of the Growth Model with Controlled Breaks}

Since the growth model is found to be co-integrated, the long run parameters of the ARDL are estimated. The study applied Akaike Information Criterion (AIC) for the selection of appropriate lags for the model. Table 6 provides the long run ARDL results on the impact of government expenditure on economic growth. From table 5 it can be deduced that at 1 percent level of significance, we established an evidence of long run relationship between capital expenditure and economic growth. This conforms to both the neo-classical and endogenous growth models that emphasized the role of capital in the process of growth and development. The finding is in line with studies conducted by Babatunde (2018) and Nyarko-Asomani et al. (2019) and contradicts studies by Saidu and Ibrahim (2019) and Ebong et al. (2016). 
Impact of Government Expenditure on Economic Growth in Nigeria,

Table 5: Estimated Long Run Coefficients Using ARDL with Breaks

\begin{tabular}{llll}
\hline $\operatorname{lnGDP}$ & Coefficient & Std. Error & P-Value \\
\hline $\operatorname{lnCAP}$ & $0.8543^{* * *}$ & 0.1917 & 0.0010 \\
$\mathrm{LF}_{t}$ & $-0.1283^{* *}$ & 0.0432 & 0.0128 \\
$\mathrm{INF}_{t}$ & $0.0049^{* *}$ & 0.0019 & 0.0298 \\
$\operatorname{lnNOILR}_{t}$ & $0.5363^{* * *}$ & 0.1671 & 0.0083 \\
$\operatorname{lnREC} t$ & -0.0080 & 0.2051 & 0.9893 \\
$\mathrm{TPN}_{t}$ & $-0.0066^{* * *}$ & 0.0011 & 0.0001 \\
$\mathrm{Break}_{t}$ & $0.0694^{* *}$ & 1.0060 & 0.0012 \\
Constant & $5.0528^{* *}$ & 2.2077 & 0.0429 \\
\hline (**) and (***) denote significance level at 5 percent and 1 \\
percent levels.
\end{tabular}

On the other hand, recurrent expenditure in the long run has a negative and insignificant impact on economic growth. The result suggests that in the long run, recurrent expenditure does not help in explaining growth and development. This has confirmed presumption of the endogenous growth model developed by Barro (1990) that considers recurrent expenditure as consumption component of government expenditure. Similarly, the study provides support to the findings of Gukat and Ogboru (2017) and contradicts studies by Idris and Bakar (2017) and Ihugba and Njoku (2017) whose findings show positive impact of recurrent expenditure on output growth.

We also established the absence of long run positive relationship between labour force and economic growth. This is in discord with the neo-classical growth models especially the Solow growth model. This could be due to high level of underemployment leading to labour inefficiency because Nigeria's civil and public services are among bloated services in the world, which is associated with inefficiency as most workers are not optimally utilized. The issue of ghost workers that characterised the federal government civil service before the application of Integrated Public Payroll and Personnel System (IPPIS) by Nigerian government could be one of the reasons for the inefficiency associated with personnel remunerations.

Inflation is found to have a long run significant positive impact on economic growth in Nigeria. The positive result is in accord with the position of the Keynesian perspective and early Phillips curve models, which held that inflation and economic growth can be positively associated when inflationary pressure induces aggregate demand and in turn encourages production. In the long run at 1 percent level of 
significance, non-oil revenue is found to be statistically significant. This implies that non-oil components of Nigerian revenue base remained very vital in promoting growth and development of Nigeria.

Lastly, trade openness shows a negative and significant nexus with economic growth at 1 percent level of significant. The result depicts that a 1 unit increase in trade openness leads to reduction in GDP by about 0.01 percent. Although, when a country engages in international trade, the expected benefit include: higher output, increase in productivity, higher income, higher investment, and so on which in turn leads to overall economic growth and development. This has not been so in the case of Nigeria going by the result obtained.

Furthermore, we estimated the short run dynamic relationship of the growth model within the framework of ARDL and the result is presented in Table 6. Interestingly, capital expenditure in the short run confirms the long run result by being positive but statistically significant only at 10 percent with economic growth. This is simply because in the short period horizon, especially at less than full employment level, rise in the capital expenditure is usually accompanied with the rising output and consequently economic growth. The finding provides support for the endogenous growth model. The result also supports previous studies by Jibir and Babayo (2015), Oyinlola, and Akinnnibosun (2013) and Nurrudeen and Usman (2010) but contradicts sharply with studies by Saidu and Ibrahim (2019) and Ebong et al., (2016).

The short run result of recurrent expenditure shows that it has a negative and significant relation with GDP. The negative impact of recurrent expenditure is in line with the presumption of the endogenous growth model developed by Barro (1990; 1991) that considers recurrent expenditure as consumption expenditure. The finding is in line with previous studies like Nurrudeen and Usman (2010) but in contrast with studies by Oyinlola and Akinnnibosun (2013) and Segun and Adelowokan (2015). This may be connected with the fact that significant portion of recurrent expenditure in Nigeria goes to payment of debt servicing during the study period. Large scale corruption in the country which allows the easy conversion of recurrent expenditure into private public office holders' accounts through the use of ghost workers, bogus budgets and expenditures and other illegal practices could be responsible for the neg- 
Impact of Government Expenditure on Economic Growth in Nigeria,

Aluthge et al.

ative association between the variables.

We also see from table 6 that, 1 percent increase in labour force reduces output by about 0.28 percent. This confirms the long run effect of the labour force given the high rate of unemployment and underemployment in Nigeria. The short run ARDL result also shows that there is negative relationship between inflation and economic growth confirming the long run result.

In the short run also, non-oil revenue depicts a positive and significant relation with economic growth at 1 percent level of significance. However, one and two years lagged of non-oil revenue reveals a negative and significant nexus with the level of output at 1 percent level of significance. This could be as a result disincentive effect of taxation which might reduce the level of productivity in the economy, and inefficiency associated with the process of collecting taxes and other non-oil revenues. Of course, multiple taxes, in government's quest to raise non-oil revenue, might adversely affect the productivity of producers.

Trade openness is statistically significant at 1 percent, and a 10 percent increase in trade openness raises the aggregate output by 0.39 . Having controlled for the structural breaks, the ARDL model confirms that as the higher the degree of the economy openness the larger the extent to which the economy expands. The coefficient of the dummy for break is found to be positive and significant indicating its effect on the overall result. 
Table 6: Short Run Error Correction Model Using ARDL

\begin{tabular}{|c|c|c|c|}
\hline$\Delta \operatorname{lnGDP}_{t}$ & Coefficient & Standard Error & P-Value \\
\hline$\Delta \operatorname{lnGDP}{ }_{t-1}$ & $0.3004 * * *$ & 0.0749 & 0.0021 \\
\hline$\Delta \operatorname{lnGDP}{ }_{t-2}$ & $0.3004 * * *$ & 0.0749 & 0.0021 \\
\hline$\Delta \operatorname{lnCAP}{ }_{t}$ & $1.2731 * * *$ & 0.3248 & 0.0024 \\
\hline$\Delta \operatorname{lnCAP}{ }_{t-1}$ & $-1.3743 * * *$ & 0.3475 & 0.0023 \\
\hline$\Delta \operatorname{lnCAP}{ }_{t-2}$ & $0.8090 * *$ & 0.3657 & 0.0490 \\
\hline$\Delta \operatorname{lnCAP}{ }_{t-3}$ & $2.7738 * * *$ & 0.2113 & 0.0000 \\
\hline$\Delta \mathrm{LF}_{t}$ & $-0.2863 * * *$ & 0.0674 & 0.0014 \\
\hline$\Delta \mathrm{LF}_{t-1}$ & $-0.2609 * * *$ & 0.0701 & 0.0034 \\
\hline$\Delta \mathrm{LF}_{t-2}$ & $0.4406^{* * *}$ & 0.0761 & 0.0001 \\
\hline$\Delta \mathrm{LF}_{t-3}$ & $-0.3837 * * *$ & 0.0575 & 0.0000 \\
\hline$\Delta \mathrm{INF}_{t}$ & $0.0038 * * *$ & 0.0003 & 0.0000 \\
\hline$\Delta \mathrm{INF}_{t-1}$ & $-0.001 * * *$ & -0.0015 & 0.0021 \\
\hline$\Delta \operatorname{lnNOILR}{ }_{t}$ & $0.2060 * * *$ & 0.0359 & 0.0001 \\
\hline$\Delta \operatorname{lnNOILR}{ }_{t-1}$ & $-0.1932 * * *$ & 0.0446 & 0.0012 \\
\hline$\Delta \operatorname{lnNOILR}{ }_{t-2}$ & $-0.1800 * * *$ & 0.0423 & 0.0014 \\
\hline$\Delta \operatorname{lnNOILR}{ }_{t-3}$ & -0.0041 & 0.0292 & 0.8906 \\
\hline$\Delta \operatorname{lnREC} C_{t}$ & $-0.2138 * * *$ & 0.0410 & 0.0003 \\
\hline$\Delta \operatorname{lnREC}{ }_{t-1}$ & $-0.2275^{* * *}$ & 0.0402 & 0.0001 \\
\hline$\Delta \operatorname{lnREC} R_{t-2}$ & -0.0630 & 0.0438 & 0.1780 \\
\hline$\Delta \operatorname{lnREC}{ }_{t-3}$ & $0.2150 * * *$ & 0.0416 & 0.0003 \\
\hline$\Delta \mathrm{TPN}_{t}$ & $0.0028 * * *$ & 0.0004 & 0.0000 \\
\hline$\Delta \mathrm{TPN}_{t-1}$ & $0.0046 * * *$ & 0.0007 & 0.0000 \\
\hline$\Delta \mathrm{TPN}_{t-2}$ & 0.0034 & 0.0006 & 0.0002 \\
\hline$\Delta \mathrm{TPN}_{t-3}$ & $0.0038 * * *$ & 0.0005 & 0.0000 \\
\hline Break $_{t}$ & $0.1170 * * *$ & 0.0129 & 0.0000 \\
\hline $\mathrm{ECT}_{t-1}$ & $-0.9031 * * *$ & 0.0792 & 0.0000 \\
\hline R-Squared & 0.9051 & & \\
\hline Adj. R-Squared & 0.9105 & & \\
\hline Durbin-Watson stat & 2.5931 & & \\
\hline Normality Test & $0.8617(0.6499)$ & & \\
\hline Serial $_{L M T e s t}$ & $2.8209(0.1240)$ & & \\
\hline Het $_{b p}$ & $0.5887(0.8811)$ & & \\
\hline
\end{tabular}

Furthermore, the coefficients of the dummies incorporated in our model in order to account for the effect of break periods identified by Bai and Perron test are found to be positive and significant at 5 percent and 1 percent significance level in the short 
Impact of Government Expenditure on Economic Growth in Nigeria, 1970-2019

Aluthge et al.

run and long run respectively, justifying controlling for the breaks in the model. This means that events such as oil boom of 1970s, the political shock of 1993 after annulment of presidential election and the regime change (from military to civilian government) in the beginning of $21^{\text {st }}$ century and so forth have significant effect on the variables included in the model. The value of adjusted $\mathrm{R}^{2}$ is 0.90 suggesting that about 90 percent of changes in output growth is explained by the independent variables. Therefore, the model can be interpreted to have a good fit considering the high percentage of the R square. Similarly, the coefficient of the ECT is found to be negative and significant at 1 percent level. This indicates that the model moves itself towards equilibrium by 90 percent annually demonstrating high convergence rate.

The study applied numerous diagnostic tests to the ARDL model with structural breaks in order to ensure robust and reliable results. From Table 7, Breuch-Godfrey normality test shows that the residuals are normally distributed. Heteroscedasticity is also not a problem and there is absence of serial correlation. Similarly, Figures 3 and Figure 4 present results of CUSUM and CUSUMSQ tests respectively. CUSUM test shows that the regression parameters of the model are relatively stable. This can be seen from the critical line that lies within the 5 percent critical level of significance.

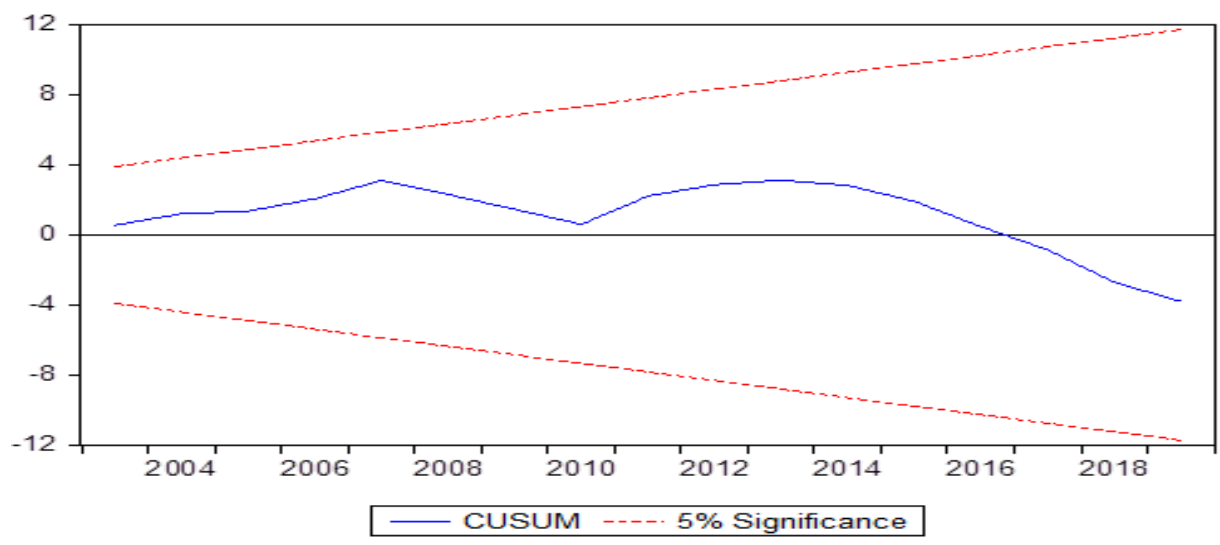

Figure 3: Plot of Cumulative Sum of Recursive Residual

On the other hand, the CUSSUMQ test shows that the model is fully stable. Nonetheless, since the CUSSUM test has confirmed that the parameters are stable, it is therefore sufficient in making inferences and concluding that the model is stable. 


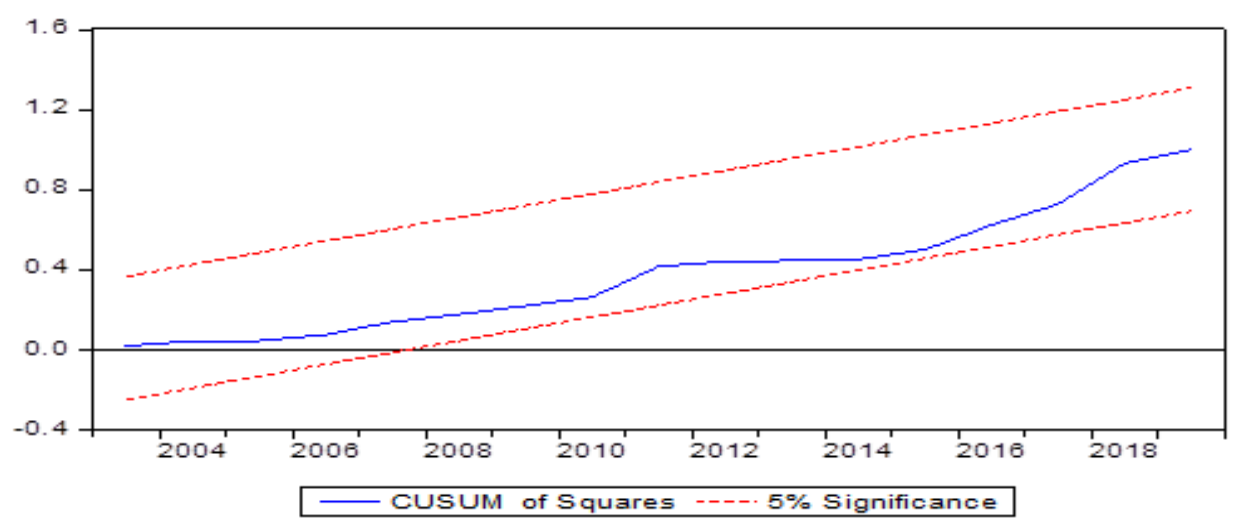

Figure 4: Plot of Cumulative Sum Squares of Recursive Residual

\section{Conclusion and Policy Recommendations}

This study has empirically examined the impact of government expenditure (disaggregated into capital and recurrent) on economic growth of Nigeria using time series data for the period 1970-2019. The paper uses Autoregressive Distributed Lag (ARDL) model. To ensure robustness of results, the study accounts for structural breaks in the unit root test and the co-integration analysis. The study argues that the empirical assessment of capital expenditure without considering the effect of depreciation which is the most common approach used by previous studies does not appear to capture the long-run effect of the variable correctly. Therefore, the study transformed public capital expenditure to a stock variable using perpetual inventory method as suggested by Berlemann and Wesselhöft (2014), Kamps (2006) and De Jong et al., (2018).

The ARDL bounds test result demonstrates the presence of a long run co-integrating relationship between all the variables in the model. Specifically, the findings of the study indicate that capital expenditure impacted positively and significantly on economic growth both in the short run and long run while recurrent expenditure does not have significant impact on economic growth both in the short run and long run. With regards to control variables included in the model, non-oil revenue and inflation have a significant positive impact on economic growth while trade openness and labour force show non-significant effect on economic growth. Relating our study with previous empirical works, our results indicate more consistency concerning the position of theory and empirics. Like Oyinlola and Akinnibosun (2013); Greiner (2014) and 
Impact of Government Expenditure on Economic Growth in Nigeria, 1970-2019

Aluthge et al.

Ebong, et al (2016) for instance; our study establish that capital expenditures positively affect economic growth in Nigeria. This is despite the inclusion of control variables in the model combined with cautious consideration to the effect of structural breaks.

The positive impact of government capital spending could be credited to the fact that most capital expenditure components enter into productive projects like bridges, roads, schools, airports, hospitals, among others, which have higher social benefits and longer paybacks - serving as a positive externality to economic activities in the economy. It is therefore recommended to the government to expand its spending share of capital expenditure to further enhance the growth of the economy, since it has been getting small share as compared to recurrent expenditure (see table 1). To ensure higher productivity of capital in promoting economic growth, capital allocations should be prioritized based on projects and areas that have strong benefits to the citizens and sound linkages with various sectors of the economy.

Recurrent expenditure is found to have significant negative impact on economic growth of Nigeria. This finding may be due to interest payment where the government uses significant portions of the recurrent expenditure as debt interest on previous borrowings. Thus, this calls for the need for government to improve the spending patterns of recurrent expenditure by focusing more on human development through appropriate expenditure switching policy. Despite its contribution to the literature, this study is not free from certain limitations. Thus, the paper pointed out areas to be considered for further research in the field. This includes extending the sample size of the study to see if long-drawn-out time series would produce analogous or dissimilar outcome and the level of disaggregation of the data should also be expanded by considering sub-categories of capital and recurrent expenditures. Though the control variables used in this study were carefully chosen after wide literature assessment, numerous other important variables may be left out which could be useful in explaining the perceived relationship between government expenditure and economic growth. Hence, different set of control variables should be considered in the future research in order to expand the debate of the impact of government expenditure on economic growth. 


\section{References}

Abu, N. \& Abdullahi, U. (2010). Government expenditure and economic growth of Nigeria, 1970-2008. A disaggregated analysis. Business and Economic Journal, 2(4), 120-135.

Ahuja, D., \& Pandit, D. (2020). Public Expenditure and Economic Growth: Evidence from the Developing Countries. FIIB Business Review, 2319714520938901.

Aigbeyisi, O. S. (2013). The relative impacts of capital and recurrent expenditures on Nigeria's economy (1980-2011). American Journal of Economics, 3(5), 210-221.

Akanbi, O. A. (2014) Government expenditure in Nigeria: determinants and trends Mediterranean Journal of Social Sciences, 5(27), 98-107.

Aladejare, S. A. (2019). Testing the robustness of public spending determinants on public spending decisions in Nigeria. International Economic Journal, 33(1), 65-87.

Ali, S., Rabbi, F., Hayat, U. \& Ali, N. (2013). The composition of public expenditures and economic growth: Evidence from Pakistan. International Journal of Social Economics, 40(11), 1010-1022.

Atilgan, E., Kilic, D. \& Ertugrul, H. (2017). The dynamic relationship between health expenditure and economic growth: is the health-led growth hypothesis valid for Turkey? The European Journal of Health Economics, 18(5), 567-574

Arrow, K. J. \& M. Kurz, (1970). Public investment, the rate of return and optimal fiscal policy (Johns Hopkins University, Baltimore, M D).

Assi, R., Dimson, J. Goodman, A. \& Andersen, J. S. (2019). Spending reviews: a more powerful approach to ensuring value in public finances. Public and Social Sector Insights, London: McKinsey \& Company.

Atilgan, E., Kilic, D., \& Ertugrul, H. M. (2017). The dynamic relationship between health expenditure and economic growth: is the health-led growth hypothesis valid for Turkey? The European Journal of Health Economics, 18(5), 567-574.

Awode, S. S. \& Akpa, E.O. (2018). Testing Wagner's law in Nigeria in the short and longrun. AUDOE, 14(7), 7-23.

Babatunde, S. A. (2018). Government spending on infrastructure and economic growth in Nigeria. Economic Research-Ekonomska Istraživanja, 31(1), 997-1014. 
Impact of Government Expenditure on Economic Growth in Nigeria,

Bai, J., \& Perron, P. (2003). Computation and analysis of multiple structural change models. Journal of Applied Econometrics, 18(1), 1-22.

Barlas, A. W. (2020). The impact of government expenditure on economic growth in Afghanistan, Journal of Economics and Business, 3(2), 729-733.

Barro, R. J. (1990). Government spending in a simple model of endogenous growth. Journal of Political Economy, 98(5), 103-125.

Barro, R. J. (1991). Economic growth in a cross section of countries. Quarterly Journal of Economics, 106, 407-443.

Berlemann, M., \& Wesselhöft, J. E. (2014). Estimating aggregate capital stocks using the perpetual inventory method: A survey of previous implementations and new empirical evidence for 103 countries. Review of Economics, 65(1), 1-34.

Bleaney, M., Gemmell, N. F. \& Kneller, R. (2001). Testing the endogenous growth model: public expenditure, taxation, and growth over long run. Canadian Journal of Economics, 34(1), 36-57.

Bose, N., Haque, M. E., \& Osborn, D. R. (2007). Public expenditure and economic growth: A disaggregated analysis for developing countries. The Manchester School, 75(5), 533-556.

Byrne, J. P., \& Perman, R. (2006). Unit roots and structural breaks: a survey of the literature. University of Glasgow, Department of Economics.

Cass, D. (1965). Optimum growth in an aggregative model of capital accumulation. Review of Economic Studies, 32(3), 233-240.

Central Bank of Nigeria (CBN) (2020). Central Bank of Nigeria Statistical Bulletin. Abuja: CBN.

Chimobi, O. P. (2016). Government expenditure and national income: A causality test for Nigeria. European Journal of Economic and Political Studies, 2(2), 1-11.

Churchill, S. A., Ugur, M., \& Yew, S. L. (2017). Does government size affect per-capita income growth? A hierarchical meta-regression analysis. Economic Record, 93(300), $142-171$.

d'Agostino, G., Dunne, J. P., \& Pieroni, L. (2019). Military expenditure, endogeneity and economic growth. Defence and Peace Economics, 30(5), 509-524. 
De Jong, J. F. M., Ferdinandusse, M., \& Funda, J. (2018). Public capital in the 21st century: as productive as ever? Applied Economics, 50(51), 5543-5560.

Devarajan, S., Swaroop, V., \& Zou, H. F. (1996). The composition of public expenditure and economic growth. Journal of Monetary Economics, 37(2), 313-344.

Dickey, D., and W. A. Fuller (1979). Distribution of the Estimates for Autoregressive Time series with Unit Root. Journal of the American Statistical Association, 74 (June), 42731.

Diyoke, K. O., Yusuf, A., \& Demirbas, E. (2017). Government expenditure and economic growth in lower middle income countries in Sub-Saharan Africa: an empirical investigation. Asian Journal of Economics, Business and Accounting, 5(4) 1-11.

Dudzevičiūtè, G., Šimelytė, A., \& Liučvaitienè, A. (2018). Government expenditure and economic growth in the European Union countries. International Journal of Social Economics, 45(2), 372-386.

Ebaid, A., \& Bahari, Z. (2019). The nexus between government expenditure and economic growth: evidence of the Wagner's law in Kuwait. Review of Middle East Economics and Finance, 15(1), 1-9.

Ebong, F., Ogwumike, F., Udongwo, U., \& Ayodele, O. (2016). Impact of government expenditure on economic growth in Nigeria: a disaggregated analysis. Asian Journal of Economics and Empirical Research, 3(1), 113-121.

Engle, R. F., \& Granger, C. W. J. (1987). Cointegration and Error Correlation: Representation, Estimation and Testing. Econometrica, 55, 251-71.

Fölster, S. \& Henrekson, M. (2001). Growth effects of government expenditure and taxation in rich countries. European Economic Review, 45(8), 1501-1520.

Forte, F. \& Magazzino, C. (2016). Government size and economic growth in Italy: a timeseries analysis. European Scientific Journal, 12(7), 149-168.

Gemmell, N., Kneller, R., \& Sanz, I. (2016). Does the Composition of Government Expenditure Matter for Long-Run GDP Levels?. Oxford Bulletin of Economics and Statistics, 78(4), 522-547.

Goldsmith, R. W. (1951). A perpetual inventory of national wealth. In Studies in Income and Wealth, NBER, 14, 5-73. 
Impact of Government Expenditure on Economic Growth in Nigeria,

Greiner, A. (2014). Public debt and the dynamics of economic growth. Annals of Economics and Finance 15(1), 185-204.

Griliches, Z. (1980). R\&D and the productivity slowdown (No. w0434). National Bureau of Economic Research.

Gukat, B. T., \& Ogboru, I. (2017). An empirical analysis of government expenditure and economic growth in Nigeria. Journal of Economics and Development Studies, 5(4),122- 134.

Gupta, R. (2018). The impact of government expenditure on economic growth in Nepal. Available at SSRN3099218. https://ssrn.com/abstract=3099218 or http://dx.doi.org/10.2139/ssrn.3099218.

Harberger, A. C. (1978). On the use of distributional weights in social cost-benefit analysis. Journal of Political Economy, 86(2, Part 2), S87-S120.

Harris, R., \& Sollis, R. (2003). Applied Time Series Modelling and Forecasting. Chichester: Wiley

Hussain, I. H., Khan, Z., \& Rafiq, M. (2017). An empirical analysis of the impact of compositional changes in public expenditure on economic growth: Time series evidence from Pakistan. Business \& Economic Review, 9(1), 1-20.

Idris, M., \& Bakar, R. (2017). Public sector spending and economic growth in Nigeria: In search of a stable relationship. Asian Research Journal of Arts \& Social Sciences, 3(2), 1-19.

Ihugba O.A., Njoku A.C. (2017). Social and community services government expenditure and Nigeria's economic growth. In: Tsounis N., Vlachvei A. (eds) Advances in Applied Economic Research. Springer Proceedings in Business and Economics. Springer, Cham. https://doi.org/10.1007/978-3-319-48454-9_5.

Jibir, A. \& Babayo, H. (2015). Impact of government expenditure and economic growth: Empirical evidence from Nigeria. IOSR Journal of Economics and Finance, 3(2), $61-68$

Jibir, A., \& Aluthge, C. (2019a). Modelling the determinants of government expenditure in Nigeria. Cogent Economics \& Finance, 7(1), 10.1080/23322039.2019.1620154.

Jibir, A. \& Aluthge, C. (2019b). Fiscal Policy Operation in Nigeria: Trends, Magnitude and Challenges. Turkey: KSP Book Publishers. 
Jibir, A., Abdullahi, S., Abdu, M., Buba, A., \& Ibrahim, B. (2018). External debt-growth nexus in Nigeria revisited. Asian Economic and Financial Review, 8(1), 117-130.

Johansen, S. (1988). Statistical Analysis of Cointegration Vectors. Journal of Economics. 3(2), 23-56.

Johansen, S., \& Juselius, K. (1990). Maximum likelihood estimation and inference on co- integration - with appucations to the demand for money. Oxford Bulletin of Economics and statistics, 52(2), 169-210.

Kamps, C. (2006). New estimates of government net capital stocks for 22 OECD countries, 1960-2001. IMF Staff Papers, 53(1), 120-150.

Katrakilidis, C. \& Tsaliki, P. (2009). Further evidence on the causal relationship between spending and economic growth: the case of Greece, 1958-2004. Acta Oeconomica, 59(1), 57-78.

King, R. \& Rebelo, S. (1990). Public policy and economic growth; developing neoclassical implications. Journal of Political Economy, 98, S126-S1511.

Kneller, R., Bleaney, M. F., \& Gemmell, N. (1999). Fiscal policy and growth: evidence from OECD countries. Journal of Public Economics, 74(2), 171-190.

Lin, E. S., Ali, H. E. \& Lu, Y. L. (2015). Does military spending crowd out social welfare expenditures? Evidence from a panel of OECD countries. Defence and Peace Economics, 26(1), 33-48.

Liu, J., Wu, S., \& Zidek, J. V. (1997). On segmented multivariate regression. Statistica Sinica, 7(2), 497-525.

Lumsdaine, R. L., \& Papell, D. H. (1997). Multiple trend breaks and the unit-root hypothesis. Review of economics and Statistics, 79(2), 212-218.

Molefe, K., \& Choga, I. (2017). Government expenditure and economic growth in South Africa: a vector error correction modeling and Granger Causality Test. Journal of Economics and Behavioral Studies, 9(4), 164-172.

National Bureau of Statistics (2019). Labor Force Statistics - Volume I: Unemployment and Underemployment Report. Abuja: NBS

Nurudeen, A. \& Usman, A. (2010). Government expenditure and economic growth in Nigeria 1970-2008. A disaggregated analysis. Business and Economic Journal, 4(3), 6382. 
Impact of Government Expenditure on Economic Growth in Nigeria,

Nyarko-Asomani, A., Bhasin, V. K., \& Aglobitse, P. B. (2019). Government capital expenditure, recurrent expenditure and economic growth in Ghana. Ghanaian Journal of Economics, 7(1), 44-70.

Oktayer, A., \& Oktayer, N. (2012). Testing Wagner's Law for Turkey: Evidence from a Trivariate Causality Analysis. Prague Economic Papers, 2, 284-301.

Olayungbo, D. O. \& OlayemI, O. F. (2018). Dynamic relationships among non-oil revenue, government spending and economic growth in an oil producing country: Evidence from Nigeria. Future Business Journal, 4(2), 246-260.

Olowu, D., Laleye, M. \& Ayeni, V. (2007). Monograph Series on Administrative Responses to the African Economic Crisis: The case of Nigeria. Nairobi, Kenya: African Association for Public Administration and Management.

Onifade, S.T., Çevik, S., Erdoğan, S., Asongu, S. \& Bekun, F. V. (2020). An empirical retrospect of the impacts of government expenditures on economic growth: new evidence from the Nigerian economy. Economic Structures 9(6). https://doi.org/10.1186/s40008-020- 0186-7

Oyinlola, M. A., \& Akinnibosun, O. (2013). Public expenditure and economic growth nexus: Further evidence from Nigeria. Journal of Economics and International Finance, 5(4), 146-154.

Perron, P. (1989). The great crash, the oil price shock, and the unit root hypothesis. Econometrica, 57(6), 1361-1401

Pesaran, M. H., Shin, Y., \& Smith, R. J. (2001). Bounds testing approaches to the analysis of level relationships. Journal of Applied Econometrics, 16(3), 289-326.

Phillips, P., \& B. Hansen (1990).'Statistical Inference in Instrumental Variables Regression with I(1) Process. Review of Economic Studies, 57:99-125.

Phillips, P. \& Perron, P. (1988). Testing for a unit root in time series regression. Biometrica 75(2), 335-346

Phiri, A. (2019). Does military spending nonlinearly affect economic growth in South Africa? Defence and Peace Economics, 30(4), 474-487. https://doi.org/10.1080/10242694.2017.1361272. 
Ram, R. (1986). Government size and economic growth: A new framework and some evidence from cross-section and time-series data. American Economic Review, 76(1), 191-203.

Saidu, I. E., \& Ibrahim, A. (2019). Impact of Public Capital Expenditure on Economic Growth in Nigeria. Lapai Journal of Economics, 3(1), 169-177.

Sala-i-Martin, X., \& Barro, R. J. (1995). Technological diffusion, convergence and growth. Centre for Economic Policy Research, London (United Kingdom). NBER Working Paper, Cambridge, 16.

Segun, O. M., \& Adelowokan, O. A. (2015). Measuring the impact of public expenditure on economic growth in Nigeria. Journal of Social Science Studies, 2(2), 46-55.

Singh, B. \& Sahni, B. S. (1984). Causality between public expenditure and national income. The Review of Economics and Statistics, 66, 630-644.

Solow, R. (1956). A contribution to the theory of economic growth. Quarterly Journal of Economics, 71, 65-94.

Srinivasan, P. (2013). Causality between public expenditure and economic growth: the Indian case. Journal of Economic and Management, 7(2), 335-340.

Ukwueze, E. R. (2015). Determinants of the size of public expenditure in Nigeria. SAGE Open, 5(4), https://doi.org/10.1177/2158244015621346.

Usman, A., Mobolaji, H. I., Kilishi, A. A., Yaru, M. A., \& Yakubu, T. A. (2011). Public expenditure and economic growth in Nigeria. Asian Economic and Financial Review, l(3), 104- 113.

Vtyurina, S. (2020). Effectiveness and equity in social spending: the case of Spain. IMF Working Paper, No. WP/20/16.

Wagner, A. (1883). Finanzwissenschaft, 1883. Leipzig, partially translated in Musgrave and Peacock.

World Bank (2008). Public Expenditure Management Handbook. Washington, D.C.: The World Bank Group.

World Bank (2015). Introduction to Public Sector Governance and Accountability Series: Public Expenditure analysis. Washington, D.C.: The World Bank Group. 
Impact of Government Expenditure on Economic Growth in Nigeria, 1970-2019

Aluthge et al.

World Bank (2020). World Development Indicators. Washington, D.C.: The World Bank Group. 